\title{
Academic Cheating in Egyptian Universities: Is It All about Corporate Code of Ethics?
}

\author{
Dr. Dina Metwally \\ Faculty of Commerce \& Business Administration, Helwan University. \\ Email: dinametwally2001@gmail.com
}

\section{Doi:10.5901/jesr.2013.v3n7p588}

\begin{abstract}
Academic cheating is one type of unethical academic behaviors or academic dishonesty. It is crucial as it affects the credibility and predictive accuracy in university admission criteria. Dealing with academic cheating requires identifying the main causes of the problem. This study aims to explore the impact of a written code of ethics in Egyptian academic institutions on cheating among undergraduate students. The study uses two cases of a private and a public academic institution. Both universities are located in Cairo. Findings indicate that the public academic institution tends to have an organizational culture that enhances ethical practices compared to the private institution. Academic cheating in both universities is influenced by a number of organizational factors including communication of ethical behavior, severity of punishment, the likelihood to be caught or reported, and influence of peer behavior. More concern for communication of ethical behavior is needed in private academic institutions to reduce the level of academic cheating among undergraduate students.
\end{abstract}

Keywords: academic cheating; ethical culture; code of ethics; undergraduate students; organizational forces.

\section{Introduction}

Managing ethical behavior is a critical problem for business organizations. However, it is difficult to understand the different factors which influence ethical behavior of organizational members. Researchers have been highly concerned with relating the ethical behavior to the corporate code of ethics, professional codes, and mission statements. The effectiveness of the corporate code of ethics has been widely examined by many researchers (e.g. Marnburg, 2000; Schwartz, 2001; Sims \& Brinkmann, 2003; McClearn, 2004). Despite research disagreement about the impact of code of ethics on the behavior of organizations, it is agreed that codes of ethics can be useful for decision making. Also, codes of ethics are valuable in conveying organizational values to stakeholders.

Meanwhile, several studies have examined the content of a corporate code of ethics (e.g. Singh et al, 2005; Kaptein, 2004; Wood, 2000; Lefebvre \& Singh, 1996; 1992; Hite et al, 1988; Mathews, 1987). Cressey \& Moore (1983) analyzed the corporate ethical code by focusing on three major elements (contents): the behaviors and actions discussed in the code, the enforcement procedures mentioned in the code, and the penalties associated with illegal actions. The three elements of analysis were the basis for a large number of studies that have focused on analyzing the content of a corporate code of ethics

Corporate codes of ethics differ from professional codes and mission statements. However, the three terms are being used interchangeably and overlap (Stevens, 1994). In its simple form, a corporate code of ethics is described as a statement setting down corporate principles, ethics, rules of conduct, codes of practice or company philosophy concerning responsibility to employees, shareholders, consumers, the environment, or any other aspects of society external to the organization' (Langlois \& Schlegelmilch, 1990; p.522). Similarly, Kaptein (2004) explains that the code of ethics clarifies the company`s values, norms, objectives and what the company can be held accountable for.

Professional codes demonstrate the 'goals and beliefs for a specific group of professionals' (Stevens, 1994, p.64). They are used to guide practitioners in their practice (Stevens, 1994). Professional codes evolve in response to social, environmental and economic standards. Nevertheless, mission statements attempt to address 'strategic management issues` (Stevens, 1994, p.64). According to Pearce \& David (1987), mission statements define the fundamental unique purpose that sets a business apart from other firms of its type and identify the scope of business. Compared to corporate ethical statements, mission statements directly address issues related to strategic planning. Mission statements are similar to corporate codes of ethics when they cover more metaphysical concepts such as values and ideals (Stevens, 1994).

In academic institutions, the issue of ethics is considerably important. Researchers have been highly concerned 
with discussing ethical and unethical actions including academic dishonesty. Academic cheating is one type of unethical academic behaviors, or academic dishonesty. Understanding causes of academic cheating is important, given the widespread and rise of cheating (McCabe et al, 2001).

Many researchers have discussed factors causing academic cheating. Despite this, there is a lack of the research discussing this issue in the Middle East, particularly in Egypt. Studying academic cheating and its causes in academic institutions as well as relating this behavior to organizational code of ethics is significant to improve the educational process. Academic cheating might take place among undergraduate and postgraduate students as well as academics. However, the level of cheating among undergraduate students has tremendously increased (e.g. Young, 1998; Donahue \& Heard, 1997; Diekhoff et al, 1996; McCabe \& Trevino, 1997; Baird, 1980). This study investigates the existence of a code of ethics in the Egyptian universities and its impact on the creation of an ethical climate. Further, the study explores the influence of codes of ethics on the level of academic cheating among undergraduate students. The aim of the study is to provide guidelines to reduce the level of academic cheating and enhance the quality of education in Egyptian universities.

\section{Ethics in organizations: climate, culture, and code of ethics}

Ethics are usually related to morality. As explained by Aldag \& Stearns (1991), business ethics reflect a set of rules that specify the sort of behaviors that the business and its employees have to follow. In business term, ethics reflect who you are and justify your actions. It is usually assumed that what is right or wrong is the same to everyone. Thus, there is no need to communicate it in a written form within the organization. Business ethics are applied ethics that reflect what is perceived as appropriate in the organization (Ralston et al, 1994; Velasquez, 1992). However, this might cause serious problems. as, It is manager's responsibility to ensure that business ethics are clear enough to all organizational members (Gbadamosi, 2004). The challenge is to communicate ethics in a way that recognizes that ethics are not obvious and similar in everyone's understanding. Gbadamosi (2004) argues that managers need to avoid too much moral dialogue that might lead to endless dilemma about ethics.

For the past 15 years, there has been an increased interest in understanding the ethical behavior/actions as well as the ethical decision-making. The growing body of literature about business ethics ensures that ethics play an important role for management both from an academic and a practitioner point of view. Also, there has been an increased concern with understanding the ethical organizational culture and climate. Ethical climate has been defined by Schneider (1975) as the stable, psychologically meaningful perceptions which the members of an organization hold concerning ethical procedures and policies. Further, Victor \& Cullen (1988) defined ethical climate as the predominant perception of organizational practices and procedures that have ethical base (Victor \& Cullen, 1988). Thus, the ethical climate of the organization is affected by the organization`s politics, procedures, practices, and reward systems. These are referred to as organization`s normative systems (Barnett \& Vaicys, 2000).

Using the same approach of Erben \& Güneşer (2008) and Dickson et al (2001), the term 'climate regarding ethics' will be used in this study instead of the term 'ethical climate`. As justified by Erben \& Güneşer (2008), this is because of two main reasons. First, ethical climate implies that the behaviors are seen as ethical in the large society. However, behaviors that might be seen as ethical within the organization may be unethical at the society level because climate is locally defined. Second, although ethical climate can be interpreted as a strong climate for ethical behaviors, identifying what is ethical differs among organizational members. Nevertheless, the term 'ethical climate implies a macro-level analysis/construct. However, the term 'climate regarding ethics' focuses on the micro-level and individual decision making in the organization (Erben \& Güneşer, 2008; Wyld \& Jones, 1997). This is useful for this research that focuses on the individual perception of ethics and its impact on decisions and behaviors within the organization.

Different organizations worldwide are concerned with developing what is referred to as a 'corporate code of ethics'. A corporate code of ethics is one of several influences on business ethics. Stajkovic \& Luthans (1997) explain that individual's perception of business ethics standards and conduct is influenced by institutional, personal, and organizational factors (e.g. code of ethics). Corporate code of ethics has been differently defined in the literature. Langlois \& Schlegelmilch (1990) define a corporate code of ethics as `a statement setting down corporate principles, ethics, rules of conduct, codes of practice or company philosophy concerning responsibility to employees, shareholders, consumers, the environment, or any other aspects of society external to the company' (p.522). These documents differ in their length, i.e. number and depth of topics covered (Singh et al, 2005).

Singh et al (2005) discuss the research concern with business ethics in general and code of ethics in particular. According to Singh et al, a code of ethics enhances organizational reputation and image. It affects the organizational 
internal and external stakeholders and hence creates a negative or a positive impression about the organization. Further, the code conveys a message that the corporation is committed to ethical behavior. Also, a corporate code of ethics could gather employees around a corporate culture, the values of which are expressed in the code. In addition, Berenbeim (2000) justifies the increased importance of corporate codes of ethics by the globalization of markets and the need for core principles that are universally applicable.

Research about ethics demonstrates that organizational climate is important in shaping employees' behaviors and attitudes. As, they provide information about what is acceptable and what is unacceptable within the organization. Further, researches report that organizational climate influences some organizational outcomes such as job satisfaction, performance and commitment (Weeks et al, 2004; Cullen et al, 2003; Treviño et al, 1998; Deshpande, 1996). However, there is a research disagreement on the effectiveness of a corporate code of ethics and its impact on the behavior of organizational members. Adams et al (2001) found that employees from companies with codes of ethics consider themselves more ethical than employees from organizations without codes of ethics. Further, Adams et al (2001) found that employees from organizations with codes of ethics are more satisfied with the outcomes of their organizations than their counterparts from organizations without codes. Similarly, Somers (2001) and Schwartz (2001) found that codes of ethics influence the ethical behavior of the organization and enhances employees' commitment. This is similar to other researchers who demonstrate a significant relationship between the code of ethics and the ethical behavior of organizational members (e.g. Stohs \& Brannick, 1999; Pierce \& Henny, 1996; McCabe et al, 1996; Ferrel \& Skinner, 1988).

Conversely, there is another body of research that reports no impact or a little impact of ethical code on organizational performance (e.g. McKendall et al, 2002; Wotruba et al, 2001; Clark \& Leonard, 1998; Mathews, 1988). Despite research disagreement on the impact of codes of ethic on the behavior of the organization, it is argued that those codes are valuable in corporate decision making and it provides a signal to stakeholders about the value of the organization (Singh et al, 2005). Singh et al (2005) argue that the existence of a code of ethics is not enough as it is important for the organization to support this code by strict compliance measures and other ethics initiatives.

Discussion of codes of ethics and their impact on organizational performance, commitment, and employee satisfaction draws attention to the existence of a code of ethics in Egyptian universities and its impact on the organizational behavior and academic cheating. Accordingly, it is important for this study to answer a number of questions including: Is a written code of ethics available in public and Egyptian private academic institutions? What is the impact of a written/unwritten code of ethics on organizational climate towards ethics? Specifically, what is the impact of a written code of ethics on academic cheating?

\section{Academic cheating: a case of unethical behavior}

Academic cheating is one type of unethical academic behaviors or academic dishonesty (McCabe et al, 2001). It may take place among undergraduate as well as postgraduate students. This study focuses on academic cheating among undergraduate students. Many researchers argue that the incidence of cheating among undergraduate students has tremendously increased (e.g. Young, 1998; Donahue \& Heard, 1997; Diekhoff et al, 1996; McCabe \& Trevino, 1993; Baird, 1980). McCabe \& Trevino (1993) indicated that more than $67 \%$ of students confessed to cheating at least once. Further, Brown $(2000,1995)$ argued that over $80 \%$ of students admitted to committing cheating at least once.

The problem in academic cheating is that it is usually unreported by faculty staff (Rawwas \& Isakson, 2000). With few exceptions (e.g. Gbadamosi, 2004), there is a lack of research on students` ethical conduct that relate academic cheating with business ethics (Brown, 2000; Rawwas \& Isakson, 2000). The importance of relating business ethics to academic cheating comes from the assumption that students, who are likely to be involved in academic cheating or at least perceive it as an acceptable behavior, would hold similar perception of business ethics and ethical value assessment (Lin, 1999; Khan, 1997; Glenn, 1992; Small. 1992; Preble \& Reichel, 1988 ).

The causes of academic cheating have been widely discussed in the literature. The most common reason for academic cheating, as reported in the literature, is getting a good grade (Meade, 1992; Nuss, 1984; Baird, 1980). Other reasons include, a lack of study time, a heavy course workload, and a low risk of getting caught (Meade, 1992; Nuss, 1984; Baird, 1980). Rawwas \& Isakson (2000) along with Michaels \& Miethe (1989) found that cheating as an unethical behavior was inversely related with the severity of punishment. This supports Buckley et al (2001) in their argument that unethical behavior is inhibited to the perceived probability of being caught as well as the severity of punishment of the behavior.

Academic cheating is crucial as it affects the credibility and predictive accuracy in university admission criteria 
(Gbadamosi, 2004; Khan, 1997). Dealing with academic cheating requires identifying the main causes of the problem. Research on academic cheating can be divided into two types: studies that focus on individuals' characteristics and their impact on cheating, and studies that relate academic cheating to organizational or situational factors (Gbadamosi, 2004; Rawwas \& Isakson, 2000). For example, gender is one of the factors that were studied in the literature to show their impact on academic cheating. Research shows different results regarding the influence of gender differences on academic cheating. Some researchers found no impact of gender differences on cheating (e.g. Sikula \& Costa, 1994; Stanga \& Turpen, 1991). Others have reported a difference between males and females with respect to academic cheating (e.g. Buckley et al, 2001; Ameen et al, 1996; Davis et al, 1992; Aiken, 1991). However, research results differed regarding which gender tends to cheat more than the other. Whilst Ameen et al (1996) found that male students engaged in unethical behavior than female students, Buckley et al (2001) reported that female students had a higher probability of being engaged in unethical behavior than their male counterparts. Age is also one of the factors that were studied in the literature to show their impact on cheating. Research argues that younger students tend to cheat more than older students (McCabe et al, 2001; Haines et al, 1986; Anton \& Michael, 1983). However, it is unclear whether this relation is due to age or class rank.

Despite the concern with studying the impact of individual factors (e.g. age \& gender), it is argued that they are less influential than contextual factors on academic cheating (McCabe \& Trevino, 1997). Contextual factors include factors such as peer cheating behavior, peer disapproval of cheating behavior, and perceived severity of penalties for cheating. Research demonstrates that peers' behavior is a crucial factor that influences academic cheating (McCabe \& Trevino, 1997; McCabe \& Trevino, 1993; Bandura, 1986). The degree to which students perceive that their peers engage in a cheating behavior was significantly related to students' cheating behavior (McCabe \& Trevino, 1993). McCabe \& Trevino (1993) concluded that peers' behavior provides a normative support for cheating. In such a climate, 'the noncheater feels left at a disadvantage ` (McCabe \& Trevino, 1993, p.533).

Gbadamosi (2004) discussed academic cheating as one type of unethical academic behavior or academic dishonesty. Gbadamosi (2004) discussed the mediating factors in academic dishonesty and referred to them as interventions. Interventions may be presented in other students who call the attention of the examiner to the incident of cheating by other students. However, research has not clarified whether calling examiners' attention to unethical behavior would make a difference in reducing academic cheating. Another intervention is teaching a course of ethics. Researchers argue that teaching a course in ethics does not make a difference in reducing unethical behavior including academic.

Discussion of different causes of academic cheating draws attention to the impact of organizational ethics. Specifically, it is important to explore the impact of codes of ethics and organizational climate towards ethics on academic cheating. Despite the importance of individual factors, this study focuses on the impact of institutional/organizational factors on academic cheating among undergraduate students. The impact of contextual factors (interventions) is also taken into consideration.

\section{Research objectives}

This study aims to explore the impact of a written code of ethics in Egyptian academic institutions on cheating among undergraduate students. To achieve this aim, the study has four main objectives. The first objective is to understand the main causes of cheating among undergraduate students. The second is to explore the impact of organizational climate towards ethics and examination misconduct. The third objective is to explore the differences between the contents of a code of ethics in private and public academic institutions. The fourth is to investigate the extent to which the contents of a code of ethics are communicated to undergraduate students in private and public academic institutions.

\section{Methodology}

This is a comparative case study research. To achieve the research aim and objectives, the study uses two cases of a private and a public academic institution. The public is the Faculty of Commerce \& Business Administration, Helwan University (HU). The private is the School of Management, the Modern University for Information \& Technology (MTI). Both universities are located in Cairo. A comparative case study allows a better understanding of each case. Further, it allows for an in-depth understanding of similarities and differences. This makes it easier to achieve the research objectives.

Three types of data were used: documentary, questionnaire, and interview data. Using different sources of data 
enhances the internal validity of the study. Further, mixing qualitative and quantitative sources of data increases the research validity and reliability. The three sources of data are discussed below:

\subsection{Documentary data}

this type of data was used to provide a background about the main themes of the study including ethics, organizational ethics, ethical climate, ethical culture, code of ethics, academic cheating, and factors that influence examination misconduct (individual and organizational). This was influential in identifying the research aim and objectives.

\subsection{Questionnaire data}

Data was collected from undergraduate students in the Faculty of Commerce \& Business Administration, Helwan University (FCHU) and School of Management, MTI University (SMMTI). Participants represented students in the departments of management, accounting and economics in Helwan University and students from the departments of finance, accounting, marketing and management in MTI University. Participants were randomly selected from undergraduate students in all academic years.

500 questionnaires were distributed randomly among undergraduate students in different departments and academic years. This included 250 questionnaires in each university. All questionnaires were returned however; only 450 questionnaires were completed and could be used. All questionnaires were anonymous. Thus, unusable questionnaires couldn't be returned back to students. Questionnaires response rate was $90 \%$.

Questionnaires were designed using Likert scale. Students were asked to express their opinions regarding a number of statements using five levels of agreement: strongly disagree (SD), disagree (D), indifferent (I), agree (A), strongly agree (SA). Questions were driven from the literature. Review of the literature summarized a number of organizational factors that influence academic cheating among undergraduate students (e.g. Gbadamosi, 2004; Rawwas \& Isakson, 2000; McCabe \& Trevino, 1997; 1993). In this study, the questionnaire covered six main dimensions: students ' cheating behavior, communication of ethical behavior, severity of punishment, influence of peer behavior, and the likelihood to be caught or reported. Each dimension was measured using a number of statements. This is shown below:

\subsubsection{Cheating behavior:}

1. I would ordinarily cheat in an examination.

2. I have never cheated in an examination.

3. If necessary, I would seek assistance from a colleague during an examination.

4. It is normal for any student to cheat, to some extent, in an examination.

5. Students must pass an exam by all means.

6. Religious beliefs have nothing to do with cheating.

\subsubsection{Communication of ethical behavior}

1. Academics and administratives spend a lot of time with students to explain the school values and ethics.

2. Students are encouraged to ask any question to know and understand rules of proper conduct during examination.

3. Seriousness of cheating and severity of punishment are stressed in every possible opportunity.

\subsubsection{Severity of punishment}

1. The seriousness of cheating is rarely mentioned by faculty staff.

2. Cheating behavior is very serious in our faculty.

3. Penalties of cheating are not strong enough to stop cheating behavior.

4. Students who have been caught cheating have not received a serious punishment. 


\subsubsection{Influence of peer behavior}

1. It is less risky to cheat when all students do.

2. I never cheat even if my colleagues do.

3. There is a less opportunity to be caught when most of students cheat.

4. Although I am not brave enough, I get the courage to cheat when all students cheat during an examination.

\subsubsection{The likelihood to be caught or reported}

1. The faculty has a rigid ethical climate.

2. Invigilation during examination is very firm.

3. Invigilators are very clever and can easily catch any student who cheats during an examination.

4. Even clever students will get caught if they cheat.

5. If I find a student cheating during an examination, I'll call the attention of the invigilator.

6. It is an appropriate behavior, if a student reports another student cheating in an examination.

7. It is not my responsibility to report a cheating student or alert the invigilator.

\subsection{Interview data}

Although the questionnaire was useful in providing an explanation of students cheating behavior and the main organizational factors that influence students cheating behavior, a more in-depth understanding of these factors was needed. To achieve this, questionnaires were followed by semi-structured interviews to gain a better understanding of questionnaires' results. 30 interviews were conducted with undergraduate students: 17 in HU and 13 in MTI University. Interviews covered the same dimensions covered in the questionnaire. However, students were given the opportunity to better explore, clarify, and discuss their opinions. To gain a better and accurate understanding about code of ethics in both universities, it was essential to interview academics and administratives. As, students were unsure about the availability of a code of ethics, its content, and the extent to which it is used. 15 interviews were conducted: 6 in $\mathrm{HU}$ and 9 in MTI. Interviews supported questionnaires' results and allowed gaining a more comprehensive view of academic cheating in public and private academic institutions.

\section{Findings}

Research findings are discussed below. The words school, faculty, university and academic institution are used interchangeably.

\subsection{Cheating behavior}

The findings of this study suggest that academic cheating among undergraduate students in private academic institutions is more than cheating in public institutions. This is shown in Table 1.

Table 1. Cheating Behavior in Private and Public Academic Institutions

\begin{tabular}{|c|c|c|c|c|c|c|c|c|c|c|}
\hline & \multicolumn{2}{|c|}{ SD } & \multicolumn{2}{|c|}{ D } & \multicolumn{2}{|c|}{ I } & \multicolumn{2}{|c|}{ A } & \multicolumn{2}{|c|}{ SA } \\
\hline & HU & MTI & $\mathrm{HU}$ & MTI & $\mathrm{HU}$ & MTI & $\mathrm{HU}$ & MTI & $\mathrm{HU}$ & MTI \\
\hline 1. I cheated in exams more than once & $30.8 \%$ & $20.3 \%$ & $28.9 \%$ & $16.7 \%$ & $12 \%$ & $8.9 \%$ & $20 \%$ & $40.8 \%$ & $8.3 \%$ & $13.3 \%$ \\
\hline 2. I might cheat in an examination & $40.2 \%$ & $8.2 \%$ & $20.6 \%$ & $9.1 \%$ & $8 \%$ & $11.1 \%$ & $18.8 \%$ & $38.3 \%$ & $12.4 \%$ & $33.3 \%$ \\
\hline 3. I have never cheated in an examination & $50 \%$ & $42.2 \%$ & $20 \%$ & $28.3 \%$ & $15 \%$ & $28.3 \%$ & 5 & $9.3 \%$ & $10 \%$ & $1.2 \%$ \\
\hline $\begin{array}{l}\text { 4. If necessary, I would seek assistance } \\
\text { from a colleague during an examination. }\end{array}$ & $38.8 \%$ & $3.5 \%$ & $20.6 \%$ & $12.6 \%$ & $6 \%$ & $20.9 \%$ & $20.8 \%$ & $38.1 \%$ & $13.8 \%$ & $24.9 \%$ \\
\hline $\begin{array}{l}\text { 5. It is normal for any student to cheat to } \\
\text { some extent in examinations. }\end{array}$ & $30.8 \%$ & $0.8 \%$ & $22.2 \%$ & $11.3 \%$ & $8 \%$ & $9.4 \%$ & $20.2 \%$ & $16.2 \%$ & $18.8 \%$ & $60.3 \%$ \\
\hline $\begin{array}{l}\text { 6. Students must pass an examination by } \\
\text { all means }\end{array}$ & $30 \%$ & $1.3 \%$ & $37 \%$ & $6.7 \%$ & $3.6 \%$ & $30.4 \%$ & $15.7 \%$ & $28.9 \%$ & $13.7 \%$ & $32.7 \%$ \\
\hline $\begin{array}{l}\text { 7. Only careless students get caught when } \\
\text { they cheat. }\end{array}$ & $20.9 \%$ & $20.4 \%$ & $17.8 \%$ & $11.2 \%$ & $32.5 \%$ & $22.7 \%$ & $11.6 \%$ & $33.2 \%$ & $17.2 \%$ & $12.5 \%$ \\
\hline
\end{tabular}


Academic cheating is influenced by a number of factors. This is shown by other research findings.

\subsection{Communication of ethical behavior}

Communication of ethical behavior reflects the faculty's code of ethics and is reflected in the organizational climate. It is possible to argue that organizations with a strong code of ethics are those that care about the communication of the organizational norms, values, and expected ethical behavior. Communication of ethical behavior to different members of the organization leads to an ethical climate that guides all organizational actions and the behavior of organizational members. Ethical behavior tends to be more important in the public faculty compared to the private one - Table 2 .

Table 2. Importance of Communicating Ethical Behavior

\begin{tabular}{|c|c|c|c|c|c|c|c|c|c|c|}
\hline & \multicolumn{2}{|c|}{ SD } & \multicolumn{2}{|c|}{ D } & \multicolumn{2}{|c|}{1} & \multicolumn{2}{|c|}{$\bar{A}$} & \multicolumn{2}{|c|}{ SA } \\
\hline & $\mathrm{HU}$ & MTI & $\mathrm{HU}$ & MTI & $\mathrm{HU}$ & MTI & $\mathrm{HU}$ & MTI & $\mathrm{HU}$ & $\mathrm{MTI}$ \\
\hline $\begin{array}{l}\text { 1. Academics and administrators in } \\
\text { my faculty spend a lot of time } \\
\text { with students explaining the } \\
\text { faculty values and ethics. }\end{array}$ & $20.7 \%$ & $40.1 \%$ & $17.8 \%$ & $22.9 \%$ & $19.1 \%$ & $13.8 \%$ & $20.1 \%$ & $11 \%$ & $22.3 \%$ & $12.2 \%$ \\
\hline $\begin{array}{l}\text { 2. Faculty staff encourages } \\
\text { students to know and abide by } \\
\text { rules of ethical behavior in } \\
\text { examination. }\end{array}$ & $19.2 \%$ & $39 \%$ & $32.6 \%$ & $30.1 \%$ & $1.6 \%$ & $3.7 \%$ & $18.9 \%$ & $9.9 \%$ & $27.7 \%$ & $17.3 \%$ \\
\hline $\begin{array}{l}\text { 3. Seriousness of cheating and } \\
\text { severity of penalties are highly } \\
\text { stressed by faculty staff. }\end{array}$ & $19.2 \%$ & $39 \%$ & $32.6 \%$ & $30.1 \%$ & $1.6 \%$ & $3.7 \%$ & $18.9 \%$ & $9.9 \%$ & $27.7 \%$ & $17.3 \%$ \\
\hline
\end{tabular}

In the public faculty, ethics in examination conduct are stressed by different organizational members (academics \& administratives) in every possible occasion. Although this is done informally, academics use the lecture rooms to stress the seriousness of cheating and the sever penalty that cheaters face. This is highly influential in reducing cheating behavior. On the contrary, organizational ethics are rarely discussed in the private school. Cheating behavior and cheating penalties are not serious points of discussion among faculty members and students.

Thus, the public academic institution tends to be more concerned with the discussion and communication of issues related to ethical behavior with undergraduate students, compared to private institutions.

\subsection{Severity of punishment}

Level of punishment and type of penalties are crucial factors that influence academic cheating. It is argued that severity of punishment reduces the level of cheating. Punishment of academic cheating in the public business school is severe.

Table 3. Punishment of Unethical Behavior

\begin{tabular}{lcccccccccc}
\hline & \multicolumn{2}{c}{$\mathrm{SD}$} & \multicolumn{2}{c}{$\mathrm{D}$} & \multicolumn{1}{c}{} & \multicolumn{2}{c}{$\mathrm{A}$} & \multicolumn{2}{c}{$\mathrm{SA}$} \\
\cline { 2 - 10 } & $\mathrm{HU}$ & $\mathrm{MTI}$ & $\mathrm{HU}$ & $\mathrm{MTI}$ & $\mathrm{HU}$ & $\mathrm{MTI}$ & $\mathrm{HU}$ & $\mathrm{MTI}$ & $\mathrm{HU}$ & $\mathrm{MTI}$ \\
& $37.2 \%$ & $11.3 \%$ & $41.2 \%$ & $7.3 \%$ & $16.2 \%$ & $19.3 \%$ & $3.3 \%$ & $39.2 \%$ & $2.1 \%$ & $22.9 \%$ \\
$\begin{array}{c}\text { 1. The seriousness of cheating is } \\
\text { rarely mentioned by faculty staff. }\end{array}$ & & & & & & & & & \\
$\begin{array}{l}\text { 2. Cheating behavior is very serious } \\
\text { in our faculty. }\end{array}$ & $20.3 \%$ & $40.8 \%$ & $8.2 \%$ & $20.9 \%$ & $0.7 \%$ & $8.3 \%$ & $33.3 \%$ & $12.7 \%$ & $38.1 \%$ & $17.3 \%$ \\
$\begin{array}{l}\text { 3. Penalties of cheating are not } \\
\text { strong enough to stop cheating } \\
\text { behavior. }\end{array}$ & $40.4 \%$ & $0 \%$ & $20.1 \%$ & $7.6 \%$ & $1.2 \%$ & $12 \%$ & $20.9 \%$ & $23.7 \%$ & $17.4 \%$ & $56.7 \%$ \\
$\begin{array}{l}\text { 4. Students who have been caught } \\
\text { cheating have not received a } \\
\text { serious punishment. }\end{array}$ & $30.4 \%$ & $2.4 \%$ & $38.9 \%$ & $13.8 \%$ & $9.8 \%$ & $18.5 \%$ & $20.1 \%$ & $44.2 \%$ & $0.8 \%$ & $21.1 \%$ \\
\hline
\end{tabular}

Whilst cheating penalty in the private business school does not exceed failure in the subject, penalty for cheating in the 
public school ranges from failure in the entire academic semester to failure in the whole academic year. As reported by students in the private school, in most cases of cheating, the invigilator does nothing more than calling the attention of the student. They reported that the most likely reaction to an incident of cheating would be failure on the test or assignment (41\%), simple warning (32\%), or nothing (27\%).

The severe punishment and penalties of academic cheating in the public business school reflects the faculty's concern for an ethical climate. This is highly influential in reducing the level of academic cheating among undergraduate students.

\subsection{Influence of peer behavior (Peers' engagement in cheating behavior)}

Peer behavior is a crucial factor that influences academic cheating in private and public academic institutions. In general, students have more courage to cheat during an examination when their fellows do. As reported by undergraduate students, it is not easy to be caught when most of students cheat during an examination. Students believe that if most of the students cheat, punishment will not be so harsh. The influence of peer behavior on academic cheating in HU and MTI is shown in Table 4.

Table 4. Influence of Peer Behavior on Academic Cheating

\begin{tabular}{lccccccccccc}
\hline & \multicolumn{2}{c}{ SD } & \multicolumn{2}{c}{ D } & \multicolumn{1}{c|}{ I } & \multicolumn{2}{c}{ A } & \multicolumn{2}{c}{ SA } \\
\cline { 2 - 11 } & HU & MTI & HU & MTI & HU & MTI & HU & MTI & HU & MTI \\
$\begin{array}{l}\text { 1. It is less risky to cheat } \\
\text { when all students do. }\end{array}$ & $9.8 \%$ & $9.3 \%$ & $24.3 \%$ & $12.2 \%$ & $8 \%$ & $9.9 \%$ & $27.7 \%$ & $40.3 \%$ & $30.2 \%$ & $28.3 \%$ \\
$\begin{array}{l}2 . \text { I never cheat even if my } \\
\text { colleagues do. }\end{array}$ & $8.6 \%$ & $23.3 \%$ & $37.8 \%$ & $37.6 \%$ & $12.2 \%$ & $27.3 \%$ & $12.6 \%$ & $7.6 \%$ & $28.8 \%$ & $4.2 \%$ \\
$\begin{array}{l}\text { 3. There is a less opportunity } \\
\text { to be caught when most of } \\
\text { students cheat. }\end{array}$ & $13.1 \%$ & $7.5 \%$ & $17.8 \%$ & $6.8 \%$ & $10.7 \%$ & $16.2 \%$ & $27.6 \%$ & $36.6 \%$ & $30.8 \%$ & $32.9 \%$ \\
\hline
\end{tabular}

\subsection{The likelihood to get caught or reported (i.e. The existence of clear rules regarding unacceptable behavior)}

The cleverness of invigilators is influential in reducing examination misconduct. Invigilation represents a major difference between the public and private institutions. This is shown in Table 5. In FCHU, the faculty applies a rigid invigilation system to reduce cheating among undergraduate students as much as possible. Invigilators are well trained and clever enough to catch cheating students. Nevertheless, they are clever enough not to give students the opportunity to cheat. This is not the case in MSMTI. Usually, the subject instructor is the invigilator. The invigilator may not be available in the examination room most of the time. As students argue, some invigilators do not take an action when they observe a case of cheating. This is a good chance for students to cheat.

Table 5. Differences in the Existence of Clear Rules Regarding Unethical Behavior

\begin{tabular}{lccccccccccc}
\hline & \multicolumn{2}{c}{ SD } & \multicolumn{2}{c}{ D } & \multicolumn{1}{c}{ I } & \multicolumn{2}{c}{ A } & \multicolumn{2}{c}{ SA } \\
\cline { 2 - 12 } & HU & MTI & HU & MTI & HU & MTI & HU & MTI & HU & MTI \\
\hline $\begin{array}{l}\text { 1. The faculty has a rigid ethical } \\
\text { climate. }\end{array}$ & $16.7 \%$ & $30.2 \%$ & $9.3 \%$ & $32.7 \%$ & $2.5 \%$ & $15.7 \%$ & $30.7 \%$ & $11.6 \%$ & $40.8 \%$ & $9.8 \%$ \\
$\begin{array}{l}\text { 2. Invigilation during examination } \\
\text { is very firm. }\end{array}$ & $14.2 \%$ & $32.2 \%$ & $9.1 \%$ & $32.7 \%$ & $4.4 \%$ & $14.6 \%$ & $24 \%$ & $8.6 \%$ & $48.3 \%$ & $11.9 \%$ \\
$\begin{array}{l}\text { 3. Invigilators are very clever and } \\
\text { can easily catch any student who } \\
\text { cheats during an examination. }\end{array}$ & $14.7 \%$ & $32.2 \%$ & $9.8 \%$ & $32.7 \%$ & $2.4 \%$ & $14.6 \%$ & $27.8 \%$ & $8.6 \%$ & $45.3 \%$ & $11.9 \%$ \\
$\begin{array}{l}\text { 4. Even clever students will get } \\
\text { caught if they cheat during an } \\
\text { examination. }\end{array}$ & $11.2 \%$ & $32.3 \%$ & $12.8 \%$ & $28.4 \%$ & $2.1 \%$ & $9.2 \%$ & $40.6 \%$ & $20.5 \%$ & $33.3 \%$ & $9.6 \%$ \\
$\begin{array}{l}\text { 5. If I find a student cheating } \\
\text { during an examination, I'll call the }\end{array}$ & $50.3 \%$ & $55.3 \%$ & $22.7 \%$ & $36.7 \%$ & $7.4 \%$ & $1.2 \%$ & $9.6 \%$ & $4.7 \%$ & $9.2 \%$ & $2.1 \%$ \\
attention of the invigilator. & & & & & & & & & \\
\hline
\end{tabular}




$\begin{aligned} & \text { 6. It is an appropriate behavior if } \\
& \text { a student reports another student } \\
& \text { cheating in an examination. }\end{aligned}$
$\begin{aligned} & \text { 7. It is not my responsibility to } \\
& \text { report another student cheating } \\
& \text { in an examination or alert the }\end{aligned}$
\begin{tabular}{l} 
invigilator. \\
\hline
\end{tabular}

The higher is the probability of a cheating student to get caught or reported, the less is the level of examination misconduct. This is all about invigilation system that reflects the code of ethics of the organization and contributes to the ethical climate.

\section{Discussion}

For many, organizational culture and climate are similar. However, they have differences and similarities (Collier \& Esteban, 2007). The word 'climate' is used to refer to the atmospheric conditions that affect the organizational values and attitudes (Collier\& Esteban, 2007). On the other hand, organizational 'culture' is related to 'the sensmaking devices that carry the different meanings within the organization such as rules, stories, codes, rituals, rewards and leadership' (Collier \& Esteban, 2007, p.24). Treviño et al (1998) regard the organizational culture as a control system as it regulates actions, governs decisions and influences behaviors within the organization. Although organizational 'climate' is highly influenced by management, 'culture` has deeper roots in corporate identity (Downey, 1986).

In practical term, the organizational climate is a part of the organizational culture. Grojean et al (2004) explain the difference between the 'climate` and 'culture 'in a simple term. According to Grojean et al (2004), the 'climate' refers to 'how things are', while the 'culture' expresses 'why things are'. It is possible to argue that the 'climate' is an invisible (intangible) part of the culture. Thus, an 'ethical culture' is the output of both organizational 'culture ' and 'climate'. Meanwhile, the ethical 'climate' is highly influenced by the corporate code of ethics. Corporate code of ethics are written statements that clarifies the company's values, norms, objectives and what the company can be held accountable for (Kaptein, 2004). Thus, the ethical 'climate' encompasses the corporate code of ethics. It is argued that the corporate code of ethics is the tangible (written) part of the culture- Figure 1.

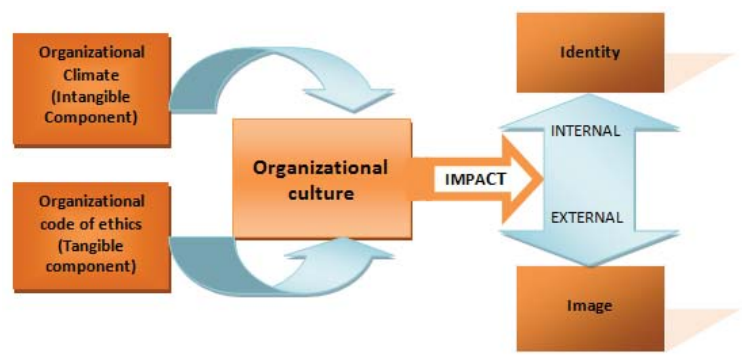

Figure 1. Organizational Ethical Context

As shown in Figure 1, the ethical 'culture' has its internal and external impact. It affects the way in which the organization is seen by outsiders, i.e. organizational 'image'. Organizational image reflects the public perceptions of the organization and how this affects organizational reputation. Also, the ethical culture affects the way organizational members perceive their own role in the environment, i.e. organizational members derive their identity from the organizational culture. Thus, in an ethical 'culture', an organization enjoys a positive 'image` and employees share a strong ethical 'identity'.

The findings of this study reports that there is an absence of a written code of ethics in the Faculty of Commerce, Helwan University (FCHU) and the School of Management, Modern University for Information and Technology (SMMTI). Despite this, FCHU tends to have an organizational culture that enhances ethical practices compared to the SMMTI. This reflects the degree of compliance to the rules and regulations of the Law of Organizing Egyptian Universities and explains differences in the image of public and private academic institutions. This law includes rules that arrange relationships within public and private universities. Penalties of cheating behaviors are also described in the law. Other 
issues related to academic misbehaviors are also described in the Law. The Law has two versions: the Law of Organizing Private Universities, and the Law of Organizing Public Universities. This draws attention to the importance of studying factors that cause difference in the degree to which academic institutions follow the rules and regulations stated by the Law. It is important to explore whether differences in fulfilling the Law occur among public academic institutions on the one hand and private institutions on the other, or is it a difference among academic institutions regardless of their type. Also, the role of leaders in creating an organizational culture/climate that respects and applies the Law needs to be investigated.

Despite the absence of a written code of ethics, public academic institutions enjoy an ethical culture. The ethical culture in public academic institutions encompasses two main elements: the ethical climate and the unwritten code of ethics (based on the Law of Organizing Public Universities). The use of unwritten code of ethics is supported in the literature as it is argued that an organizational culture may supersede a written code of ethics however; a written code is a mere formality (Sims \& Brinkmann, 2003). James (2000) argues that written codes are not necessary however; they can be useful in articulating the organizational values to the public.

The ethical culture in FCHU stresses the strong punishment of cheating. It is created through a heightened level of moral and ethical awareness. The ethical awareness creates a positive climate regarding ethics. As reported in the literature, ethical awareness and ethical climate compose an ethical organizational culture (Verbos et al, 2007).

Regarding cheating, ethics in the FCHU are transmitted verbally to undergraduate students. What is 'right', 'moral' or 'unethical' in exams is transmitted to undergraduate students informally using the word of mouth from the following sources: academic staff, administrative staff, and elder students. Thus, organizational culture in the FCHU conveys a message that cheating is a 'wrong', 'unethical', 'unacceptable' behavior that is strongly punished. However, this ethical awareness is created informally. This is because of the absence of a written code of ethics that clearly sets ethical norms, values, and standards. This written code obliges the faculty and its members to formally promote an organizational culture that encourages ethical conduct and a commitment to ethical behaviors. Creating an ethical culture against cheating is based on creating a moral awareness among undergraduate students. This culture influences the school image. Thus, students who join the school are aware in advance of the seriousness of cheating. Accordingly, undergraduate students in public business schools cheat less than their counterparts in private schools.

\section{Reducing academic cheating in private institutions: recommended strategies}

This study aimed to understand causes of academic cheating among undergraduate students and the impact of organizational ethics. The focus was organizational rather than individual factors. A comparison between a private and a public business school (faculty) reported that academic cheating is a serious problem in private academic institutions. Despite the absence of a written code of ethics in both private and public institutions, organizational culture in the public school promotes an ethical climate that is influential in reducing academic cheating.

The absence of a written code of ethics gives an opportunity to unethical behavior to take place. This emphasizes the importance of implementing different strategies for promoting ethical behavior and moral awareness as well as managing cheating behavior- Table 6 . This cannot be achieved without supporting faculty members who apply serious charges of student dishonesty. Academic institutions must promote an ethical climate that convinces students that cheating is not the rule, it is an exception.

Table 6. Useful Strategies for Promoting Ethical Behavior

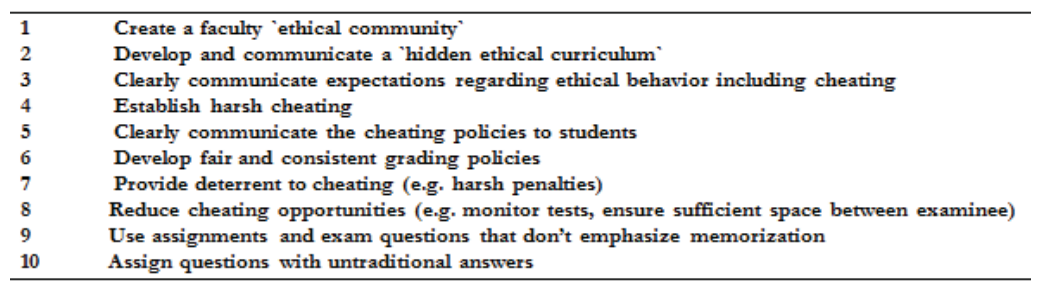

Source: Adopted from McCabe, D. L., Treviño, L. K., \& Butterfield, K. D. (1999) `Academic Integrity in Honor Code and NonHonor Code Environments: A Qualitative Investigation', Journal of Higher Education, 70: 211-234. \& McCabe, D., Trevino, L., Butterfield, K (2001) 'Cheating in Academic Institutions: A Decade of Research', Ethics \& Behavior, 11(3): 219-232. 
Findings of this study provide numerous insights that faculty, administrators, academics, and students can use to reduce the level of academic cheating. It is argued that institutional factors are highly influential in reducing the level of cheating. Although the existence of a written code of ethics can be a useful tool to reduce cheating, their absence does not necessarily mean unethical behavior. Academic institutions are highly advised to create an 'ethical community'. This ethical community should be responsible for the formal communication of ethical rules and standards, moral awareness of organizational members, and promoting mutual respect between students and faculty member (McCabe et al, 2001). Whether in public or private institutions, this ethical community is expected to raise moral awareness, promote for ethical behavior and reduce the level of academic cheating.

Also, the use of a 'hidden ethical curriculum', as suggested by McCabe et al (2001), is helpful. This curriculum is useful in reducing the level of academic cheating especially with the lack of a written code of ethics. The 'hidden curriculum 'is used to provide formal ethics instructions and to raise students' awareness about day-to-day ethical issues. Also, the curriculum can be useful in discussing ethical issues with students and how to act on them. Communication of the 'hidden curriculum` should be done inside as well as outside the lecture rooms (Trevino \& McCabe, 1994).

Reducing cheating in academic institutions relies on linking faculty and students. It is significant to relate students to faculty in their views regarding cheating. This is influential in integrating faculty and students 'efforts toward the goal of establishing an ethical community. Also, the type of exam questions influences cheating behavior. It is highly recommended to avoid traditional exam questions that measures students' ability to memorize. Whilst this type of questions increases level of cheating, questions with nontraditional answers that encourage creativity reduces cheating. Further, arrangement of exam area is significant. The exam room should be arranged in a way that provides sufficient space between students. Students should be seated in a way that makes it difficult for each student to read the answer sheet of any other student clearly. Invigilators must be well trained and clever enough to catch up any cheating intention.

As shown by the findings of this study, peer behavior highly influences cheating behavior. Although new faculty students ( $1^{\text {st }}$ year students) represent only a small percentage of the total number of students, it is important to give them a message that cheating is unacceptable and harshly penalized. The most influential way to convey this message is through the peer behavior. When new students observe a cheating behavior from elder students that is ignored by faculty, they are convinced that cheating is acceptable or at least not harshly penalized. To survive and be competitive in this environment, new students are convinced that they must follow the same behavior of their peers.

\section{Future research}

This study is considered as the first step in the research about ethics and academic dishonesty in Egypt. However, the findings are limited to the Faculty of Commerce and Business Administration, Helwan University (a public business school) and the School of Management, Modern University for Information \& Technology (a private business school). It is significant to study similar research issues in other public and private academic institutions in Egypt. It is useful to apply the same study in other public and private business schools as this is useful in generalizing research findings.

Regarding academic dishonesty, particularly cheating behavior, there is a need to study influential factors in academic institutions with other specialties (not only business and management). This is useful to demonstrate the impact of the functional area on organizational code of ethics and academic dishonesty. This is also useful to answer the questions: is the written code of ethics used in other academic institutions with other specialties? Does cheating have a different meaning in different specialties? i.e. Are ethics defined similarly, or is it something relative?

Further, this study reports that, with the absence of a written code of ethics, ethical climate is the reference. What factors forms an ethical climate is an issue that should be further investigated. There is a need to explore different factors that make a faculty climate ethical/unethical. An important question that arises here is regarding the impact of leadership: are leaders primarily responsible for creating an ethical climate? If yes, what is the type of leadership that can pursue an ethical organizational climate and support academic honesty?

Nevertheless, an interesting issue to be studied is the impact of national culture on organizational culture, ethics, ethical climate and academic cheating. Thus, applying the same study in other Middle Eastern countries would be a new area of research.

\section{Conclusion}

Managing ethical behavior is a critical problem for business organizations. Researchers have been highly concerned with relating the ethical behavior to the corporate code of ethics, professional codes, and mission statements. This study 
aimed to study the main organizational factors responsible for academic cheating in Egyptian academic institution and the influence of a corporate code of ethics. A comparative study was used to gain in-depth understanding of the research questions. The study concluded that there is an absence of a corporate code of ethics in its written form in Egyptian public and private academic institutions. Despite this, the public institution has an ethical organizational culture that applies harsh penalties and punishment of unethical behaviors. The ethical climate along with the unwritten code of ethics is the heart of this organizational culture.

The ethical culture in the public academic institutions influences academic cheating. Findings of this study suggest that cheating among undergraduate students in the public academic institution is less than cheating among their counterparts in the private institution. Organizational factors that influence academic cheating among undergraduate students include: communication of ethical behavior, severity of punishment, the likelihood to be caught or reported, and influence of peer behavior. More concern for communication of ethical behavior is needed in private academic institutions to reduce the level of academic cheating. Also, punishment of cheating must be harsh enough to stop students from any intention to cheat.

\section{References}

Adams, J., Tasachian, A. \& Stone, T. (2001) 'Codes of Ethics as Signals for Ethical Behavior', Journal of Business Ethics, 29(3): 199211.

Aiken, L.R. (1991) 'Detecting, Understanding, and Controlling for Cheating on Tests', Research in Higher Education, 32: 725-736.

Aldag, R. \& Stearns, T. (1991) 'Management', (USA: Cengage South Western).

Ameen, E., Guffey, D. \& McMillan, J. (1996) 'Gender Differences in Determining the Ethical Sensitivity of Future Accounting Professionals', Journal of Business Ethics, 15: 591-597.

Anton, D.L. \& Michael, W.B. (1983) 'Short-term Predictive Validity of Demographic, Affective, Personal, and Cognitive Variables in Relation to 2 Criterion Measures of Cheating Behaviors', Educational and Psychological Management, 43: 467-483.

Baird, J.S. (1980) 'Current Trends in College Cheating', Psychology in the Schools, 17(4): 515-522.

Bandura, A. (1986) 'Social Foundations of Thought and Action', (Englewood Cliffs, NJ: Prentice Hall).

Barnett, T. \& Vaicys, C. (2000) 'The Moderating Effect of Individuals' Perceptions of Ethical Work Climate on Ethical Judgments and Behavioral Intentions', Journal of Business Ethics, 27(4): 351-362.

Berenbeim, R. (2000) 'Global Ethics', Executive Excellence, 17(5): 7.

Brown, B.S. (1995), 'The Academic Ethics of Graduate Students: A Survey `, Journal of Education for Business, 70 (3): 151-157.

Brown, B.S. (2000), 'The Academic Ethics of Graduate Business Students: 1993 to 1998', Journal of Applied Business Research, 16(4): 105-113.

Buckley, M.R., Beu, D.S., Frink, D.D., et al. (2001) 'Ethical Issues in Human Resource Systems'. Human Resource Management Review, 11: 11-29.

Burton, B. \& Near, J. (1995) 'Estimating the Incidence of Wrongdoing and Whistle-Blowing: Results of a Study Using Randomized Response Technique', Journal of Business Ethics, 14(1): 17-30.

Clark, M.A. \& Leonard, S.L. (1998) 'Can Corporate Codes of Ethics Influence Behavior? ', Journal of Business Ethics, 17(6): 619-630.

Collier, J. \& Esteban, R. (2007) 'Corporate Social Responsibility and Employee Commitment', Business Ethics, 16(1): 19-33.

Cressey, D.R. \& Moore, C.A. (1983) 'Managerial Values and Corporate Code of Ethics', California Management Review, 25(4): 53-77.

Cullen, J.B., Parboteeah, K. \& Victor, B. (2003) 'The Effects of Ethical Climates on Organizational Commitment: A Two Study Analysis', Journal of Business Ethics, 46: 127-141.

Davis, S.F., Grover, C.A., Becker, A.H., et al (1992) 'Academic Dishonesty: Prevalence, Determinants, Techniques, and Punishment', Teaching of Psychology, 19: 16-20.

Deshpande, S.P. (1996) 'The Impact of Ethical Climate Types on Facets of Job Satisfaction: An Empirical Investigation', Journal of Business Ethics, 15(6): 655-660.

Dickson, M., Smith, M.W., Grojean, M.C., et al (2001) 'An Organizational Climate Regarding Ethics: The Outcome of Leader Values and the Practices that Reflect them', Leadership Quarterly, 12: 197-214.

Diekhoff, G.M., Emily, E.L., Robert, E.C., et al (1996) 'College Cheating: Ten Years Latter', Research in Higher Education, 37(4): 487502.

Donahue, B. \& Heard, A. (1997) 'Cheat Feats', New York Times Magazine, 146(50789): 15.

Downey, G. (1986) 'Risk in Culture: The American Conflict over Nuclear Power', Cultural Anthropology, 1(4): 388-412.

Erben, G. \& Güneşer, A. (2008) 'The Relationship between Paternalistic Leadership and Organizational Commitment: Investigating The Role of Climate Regarding Ethics', Journal of Business Ethics, 82(4): 955-968.

Ferrell, O.C. \& Skinner, S.L. (1988) 'Ethical Behaviour and Bureaucratic Structure in Marketing Research Organizations', Journal of Marketing Research, 25: 103-109.

Gbadamosi, G. (2004) 'Academic Ethics: What has morality, culture and administration got to do with its measurement?', Management Decision, 42(9): 1145 - 1161.

Glenn, J.R. (1992) 'Can a Business and Society Course Affect the Ethical Judgment of Future Managers?', Journal of Business Ethics, 
11(3): 217-223.

Grojean, M.W., Resick, C.J., Dickson, M.W., et al (2004) 'Leaders, Values and Organizational Climate: Examining Leadership Strategies for Establishing and Organizational Climate Regarding Ethics', Journal of Business Ethics, 55: 223-241.

Haines, V.J., Diekhoff, G.M., LaBeff, E. E., et al (1986) 'College Cheating: Immaturity, Lack of Commitment and the Neutralizing Attitude', Research in Higher Education, 25: 342-354.

Helin, S. \& Sandström, J. (2007) 'An Inquiry into the Study of Corporate Codes of Ethics`, Journal of Business Ethics, Spring, 75: 253271.

Hite, R., Bellizzi, A. \& Fraser, C. (1988) 'A Content Analysis of Ethical Policy Statements Regarding Marketing Activities', Journal of Business Ethics, 7(9): 711-776.

James, H.S., Jr. (2000) 'Reinforcing Ethical Decision-making through Organizational Structure`, Journal of Business Ethics, 28: $43-58$.

Kaptein, M. (2004) 'Business Codes of Multinational Firms: What Do They Say?', Journal of Business Ethics, 50(1): 13-31.

Khan, S. (1997) 'The Key to be a Leader Company: Empowerment', Journal for Quality \& Participation, 20(1): 44-50.

Langlois, C.C. \& Schlegelmilch, B.B. (1990) 'Do Corporate Codes of Ethics Reflect National Character? Evidence from Europe and the United States', Journal of International Business Studies, Fourth Quarter, pp: 519-536.

Lefebvre, M. \& Singh, J. (1992) 'The Content and Focus of Canadian Corporate Codes of Ethic', Journal of Business Ethics, 11: 799808.

Lefebvre, M. \& Singh, L. (1996) 'A Comparison of the Contents and Foci of Canadian and American Corporate Codes of Ethics', International Journal of Management, 13(2): 156-171.

Lin, Y.Y. (1999) 'A Comparison of Perceptions about Business Ethics in Four Countries', The Journal of Psychology, $133(6)$ : $641-655$.

Marnburg, E. (2000) 'The Behavioral Effects of Corporate Ethical Codes: Empirical Findings and Discussion', Business Ethics: $A$ European Review, 6(3): 220-210.

Mathews, M.C. (1987) 'Codes of Ethics: Organizational Behavior and misbehavior Research in Corporate Social Performance and Policy ', Empirical Studies of Business Ethics and Values, 9: 107-130.

Mathews, M.C. (1988) 'Strategic Intervention in Organizations: Resolving Ethical Dilemmas', (Newbury Park, California: Sage Publications).

McCabe, D.L., \& Trevino, L.K. (1993) `Academic Dishonesty: Honor Codes and Other Contextual Influences’, Journal of Higher Education, 64: 522-538.

McCabe, D. \& William, J. (1994) 'Academic Dishonesty among Males in College: A Thirty Year Perspective`, Journal of College Student Development, 35(1): 5-10.

McCabe, D.L., Trevino, L.K. \& Butterfield, K.D. (1996) 'The Influence of Collegiate and Corporate Codes of Conduct on Ethics-Related Behavior in the Workplace', Business Ethics Quarterly, 6(4): 461-476.

McCabe, D.L. \& Trevino, L.K. (1997) 'Individual and Contextual Influences on Academic Dishonesty: A Multicampus Investigation`, Research in Higher Education, 38: 379-396.

McCabe, D. L., Treviño, L. K. \& Butterfield, K. D. (1999) 'Academic Integrity in Honor Code and Non-Honor Code Environments: A Qualitative Investigation', Journal of Higher Education, 70: 211-234.

McCabe, D., Trevino, L. \& Butterfield, K. (2001) 'Cheating in Academic Institutions: A Decade of Research`, Ethics \& Behavior, 11(3): 219-232.

McClearn, M. (2004) ‘Did Anybody Even Read This?’, Canadian Business, May24-June6, p.14.

McKendall, M., DeMarr, B. \& Jones-Rikkers, C. (2002) `Ethical Compliance Programs and Corporate Illegality: Testing the Assumptions of the Corporate Sentencing Guidelines', Journal of Business Ethics, 37: 367-383.

Meade, J. (1992) 'Cheating: Is Academic Dishonesty Par for the Course? ', Prism, 1(7): 30-32.

Michaels, J.W. \& Miethe, T. D. (1989) 'Applying Theories of Deviance to Academic Cheating', Social Science Quarterly, 70: 870-885.

Nuss, E. M. (1984) 'Academic Integrity: Comparing Faculty and Student Attitudes ', Improving Collegeand University Teaching, 32: 140144.

Pearce, J. \& David, F. (1987) 'Corporate Mission Statements: The Bottom Line', Academy of Management Executive, 1(2): $109-116$.

Pierce, M.A. \& Henry, J.W. (1996) 'Computer Ethics: the Role of Personal, Informal, and Formal Codes', Journal of Business Ethics, 15: 425-437.

Preble, J.F. \& Reichel, A. (1988) 'Attitudes towards Business Ethics of Future Managers in the U.S. and Israel', Journal of Business Ethics, 7(12): 941-949.

Ralston, D.A., Giacalone, A.R. \& Terpstra, R.H. (1994) `Ethical Perception of Organizational Politics: A Comparative Evaluation of American and Hong Kong Managers', Journal of Business Ethics, 13(12): 989-999.

Rawwas, M.Y.A. \& Isakson, H.S. (2000) 'Ethics of Tomorrow's Business Managers', Journal of Education for Business, 75: 321-330.

Schneider, B. (1975) 'Organizational Climates: An Essay', Personnel Psychology, 28(4): 447-479.

Schwartz, M. (2001) 'The Nature of the Relationship between Corporate Codes of Ethics and Behavior', Journal of Business Ethics, 32: 247-262.

Sikula, A.Sr. \& Costa. A.D. (1994) 'Are Women More Ethical than Men? ', Journal of Business Ethics, 13: 859-871.

Sims, R. \& Brinkmann, J. (2003) 'Culture Matters more than Codes', Journal of Business Ethics, 45: 243-256.

Singh, J., Svensson, G. \& Wood, G. (2005) 'A Comparative Study of the Contents of Corporate Codes of Ethics in Australia, Canada and Sweden', Journal of World Business, 40(1): 91-109.

Small, M.W. (1992) `Attitudes towards Business Ethics Held by Western Australian Students: A Comparative Study`, Journal of 
Business Ethics, 11: 745-752.

Somers, M.J. (2001) 'Ethical Codes of Conduct and Organizational Context: A Study of the Relationship between Codes of Conduct, Employee Behavior and Organizational Values', Journal of Business Ethics, 30(2): 185-195.

Stajkovic, A.D. \& Luthans, F. (1997) 'Business Ethics across Cultures: A Social Cognitive Model', Journal of Business Ethics, 32(1): 1734.

Stanga, K. \& Turpen, R. (1991) 'Ethical Judgment on Selected Accounting Issues: An Impirical Study', Journal of Business Ethics, 10(10): 739-747.

Stead, W.E., Worrell, D.L., Spalding, J.B., et al (1987) 'Unethical Decisions: Socially Learned Behaviors', Journal of Social Behavior and Personality, 2(1): 105-15.

Stead, W.E., Worrell, D.L. \& Stead, J.G. (1990) 'An Integrative Model for Understanding and Managing Ethical Behavior in Business Organizations', Journal of Business Ethics, 9: 233-242.

Stevens, B. (1994) 'An Analysis of Corporate Ethical Code Studies: Where Do We Go From Here?', Journal of Business Ethics, 13: 6369.

Stohs, J.H. \& Brannick, T. (1999) 'Codes of Conduct: Predictors of Irish Managers Ethical Reasoning', Journal of Business Ethics, 22: 311-329.

Trevino, L. \& McCabe, D. (1994) 'Meta Learning about Business Ethics: Building Honorable Business School Communities', Journal of Business Ethics, 13: 405-416.

Treviño, L.K., Butterfield, K.B. \& McCabe, D.L. (1998) 'The Ethical Context in Organizations: Influence on Employee Attitudes and Behaviors', Business Ethics Quarterly, 8(3): 447-76.

Velasquez, M.G. (1992) 'Business Ethics: Concepts and Cases', (Englewood Cliffs, NJ: Prentice-Hall).

Verbos, A.K., Gerard, J.A., Forshey, P.R., et al (2007) 'The Positive Ethical Organization: Enacting a Living Code of Ethics and Ethical Organizational Identity', Journal of Business Ethics, 76: 17-33.

Victor, B. \& Cullen, J. (1988) 'The Organizational Bases of Ethical Work Climates', Administrative Science Quarterly, 33(1): 101-125.

Ward, D.A. (1986) 'Self-esteem and Dishonest Behavior Revisited', Journal of Social Psychology, 126: 709-713.

Weeks, W.A., Loe, T.W., Chonko, L.B., et al (2004), 'The Effect of Perceived Ethical Climate on the Search for Sales Force Excellence,' Journal of Personal Selling \& Sales Management, 24: 199-214.

Wood, G. (2000) 'A Cross Cultural Comparison of the Content of Codes of Ethics: USA, Canada and Australia', Journal of Business Ethics, 25: 287-298.

Wotruba, T.R., Chonko, L.B. \& Loe, T.W. (2001) 'The Impact of Ethics Code Familiarity on Manager Behavior', Journal of Business Ethics, 33: 59-69.

Wyld, D.C. \& Jones, C.A. (1997) 'Importance of Context: The Ethical Work Climate Construct and Models of Ethical Decision-Making An Agenda for Research', Journal of Business Ethics, 16, 465-472.

Young, K. (1998) 'College Cheating on the Rise', Charleston Daily Mail, October, pp: 1A-11A. 